\title{
The incidence of rotavirus infection compared to bacterial infections in different age groups of pediatric patients with gastroenteritis
}

Original scientific article

Received: 28. 05. 2019

Accepted: 24. 07. 2019

Published: 31. 12. 2019
${ }^{1}$ Center for Microbiology, Public Health Institute Niš, Bul. Dr Zorana Đinđića 50, 18000 Niš, Republic of Serbia

${ }^{2}$ University of Niš, School of Medicine, Bul. Dr Zorana Đinđića 81, 18000 Niš, Republic of Serbia

* Corresponding author dr. Tatjana Babić, dr. sc. med. Center for Microbiology, Public Health Institute Niš, Bul. Dr Zorana Đinđića 50, 18000 Niš, Republic of Serbia E-mail: tatjanab969@yahoo.com

(c) 2019 Tatjana Babić et al. This is an open access article licensed under the Creative Commons Attribution-

NonCommercial-NoDerivsLicense (http:// creativecommons.org/licenses/by-nc$\mathrm{nd} / 3.0 /$ ).

\author{
Tatjana BABIĆ ${ }^{1 *}$, Biljana MILJKOVIĆ-SELIMOVIĆ ${ }^{2}$, \\ Dobrila ĐORĐEVIĆ-STANKOVIĆ ${ }^{2}$, Branislava KOCIĆ2 \\ Miloš RANĐELOVIĆ ${ }^{1}$, Predrag STOJANOVIĆ ${ }^{2}$, \\ Milena BOGDANOVIĆ ${ }^{1}$, Vukica ĐORĐEVIĆ ${ }^{2}$
}

\section{ABSTRACT}

Rotavirus is the important cause of acute gastroenteritis in pediatric patients. The aim of the present research was to determine the incidence of rotavirus infections in infants and children up to seven years of age in the town of Niš. Seasonal prevalence of rotavirus-associated acute gastroenteritis was also evaluated. An enzyme immunoassay (RIDASCREEN ${ }^{\circledR}$ Rotavirus; R-Biopharm AG, Darmstadt, Germany) was used to detect rotavirus in the stool specimens of 1,156 patients (newborns up to 7 years of age) presenting with gastroenteritis. Identification of bacteria and yeasts was performed by classical methods. The overall incidence of rotavirus in examined children was $5.97 \%$. Among 144 hospitalized children, rotavirus infection was diagnosed in 28 (19.44\%). In 1,012 children treated in outpatient setting for diarrheal diseases, rotaviruses were found in 41 (4.05\%). The highest incidence of rotavirus infection was among the patients of one year of age. Among 1,156 pediatric children tested, bacterial pathogens were found in $6.31 \%$ and the most frequently isolated pathogens were Campylobacter spp. and Salmonella enteritidis. The highest prevalence of GE was recorded in the colder season, peaking in April (15.94\%). Rotaviruses are an important factor in the etiology of the acute diarrheal diseases, especially in children hospitalized during the winter/spring season.

Key words: rotavirus; gastroenteritis; incidence; children

\section{POVZETEK}

Rotavirus je pomemben vzrok akutnega gastroenteritisa pri otrocih. Namen predstavljene raziskave je ugotoviti pojavnost rotavirusnih okužb pri dojenčkih in otrocih do sedmega leta starosti v mestu Niš. Ocenjena je bila tudi sezonska razširjenost rotavirusa povezanega $z$ akutnim gastroenteritisom. Za odkrivanje rotavirusa v vzorcih blata pri 1156-ih bolnikih (novorojenčki in otroci do sedmega 
Rotavirus (RV) has been shown to be the leading cause of severe acute diarrhea in pediatric patients.

Seasonal distribution of rotavirus cases may vary by geographical location. leta starosti) z gastroenteritisom, je bil uporabljen encimski imuno test (RIDASCREEN ${ }^{\circledR}$ Rotavirus; R-Biopharm AG, Darmstadt, Germany). Identifikacija bakterij in kvasovk je bila izvedena s klasičnimi metodami. Skupna pojavnost rotavirusa med pregledanimi otroci je bila 5,97\%. Med 144 hospitaliziranimi otroki, je okužba z rotavirusom bila diagnosticirana pri 28-ih (19,44 \%). Pri 1012 otrocih, ki so jih zdravili v ambulanti, zaradi diarejskih bolezni, so rotavirusi bili najdeni pri 41-ih (4,05\%). Najvišja pojavnost rotavirusnih okužb je bila pri enoletnih otrocih. Med 1156 testiranimi otroci, so bili bakterijski patogeni najdeni pri $6,31 \%$, najpogosteje izolirani patogeni so bili Campylobacter spp. in Salmonella enteritidis. Največja razširjenost GE je bila zabeležena v hladnejši sezon, z vrhuncem $v$ aprilu $(15,94 \%)$. Rotavirusi so pomemben dejavnik v etiologiji akutnih diarejskih bolezni, še posebej pri otrocih hospitaliziranih $\vee$ zimski/pomladni sezoni.

Ključne besede: rotavirus; gastroenteritis; pojavnost; otroci

\section{INTRODUCTION}

Rotavirus (RV) has been shown to be the leading cause of severe acute diarrhea in pediatric patients [1, 2]. This segmented double-stranded RNA $(60-80 \mathrm{~nm})$ viruses belong to the family Reoviridae. They are classified into seven serogroups (A-G) based on electrophoretic mobility of genomic segments and group-specific VP6 antigen of the internal capsid [3]. Further division to serotypes is based on dominant antigens VP4/VP7 of external capsid. Viruses of the serogroup A cause human disease and serogroups $B$ and $C$ are rarely involved [4].

Clinical presentation of human RV infection can vary from asymptomatic, mild or severe gastroenteritis (GE) disease that can result in a lethal dehydration. Clinical manifestations are a sudden onset of vomiting, diarrhea lasting 5-6 days on the average, and dehydration [5]. In some patients, mucosal infection can spread systemically with viral replication in different parts of the body [6]. Oral rehydration corrects the electrolyte and water loss, indicating that enterocytes in the small intestine have a functional sodium-glucose co-transporter [7].

The highest rate of infection has been reported in patients 6 to 24 months of age [8] in both developed and developing countries. However, deaths due to RVGE (Rota viral gastroenteritis) occur mainly in the low income countries of Asia, Africa and Latin America among the children below 5 years of age [9]. RV causes almost 111 million gastroenteritis (GE) episodes, 25 million clinical visits, 2 million hospitalizations and more than 453,000 deaths each year [10].

Seasonal distribution of rotavirus cases may vary by geographical location: in temperate climates most cases are observed in fall, winter and spring months [11], while in tropical countries there are not seasonal peaks [12].

Electron microscopy analysis has proven to be a valuable technique in the diagnosis of these agents in patients with acute infections. However, enzyme immunoassays are rapid, sensitive, and specific alternatives to electron microscopy providing the detection of infectious agents in 
diarrheal stools specimens [13]. There are several commercial enzyme immunoassay kits which enable detection of all serotypes of group $A$ rotaviruses [14]. Molecular techniques, for example reverse transcription-polymerase chain reaction (RT-PCR), enable diagnosis and identification of all serogroups and serotypes of human rotavirus [15].

Limited data exist on the importance of rotavirus in the etiology of diarrheal disease in all parts of Serbia due to a lack of detection and reporting policy of microbiological laboratories.

The objectives of the present prospective study was to determine the incidence of rotavirus infection in infants and children up to seven years of age presenting with GE, distribution of infection by the factors of age and gender, association between the infection caused by rotaviruses and bacteria, and seasonal prevalence of rotavirus-associated acute gastroenteritis.

\section{METHODS}

\section{Patients}

In the Center for Microbiology, Public Health Institute Niš, stool specimens from 1,156 pediatric patients (newborns up to 7 years of age) presenting with GE were processed for bacteriology testing and for detection of rotaviruses over a two-year period (January 2009 - July 2010).

\section{Rotavirus detection}

Rotavirus was detected from fresh, unfrozen samples of diarrheal stools. An enzyme immunoassay (RIDASCREEN ${ }^{\circledR}$ Rotavirus; R-Biopharm AG, Darmstadt, Germany) was used to detect rotavirus in the stools specimens according to the manufacturer's instructions.

\section{Bacterial detection and identification}

For bacterial detection, fecal samples were processed by standard bacteriological methods for Salmonella spp., Shigella spp., Yersinia enterocolitica (Y. enterocolitica), Bacillus cereus (B. cereus), and Campylobacter spp. Diarrheal toxins of $B$. cereus were confirmed using the GLISA-Rapid Test (Gold Labelled ImmunoSorbent Assay) for the qualitative detection of enterotoxin producing $B$. cereus: Duopath ${ }^{\circledR}$ Cereus for the determination of the NHE and HBL enterotoxins (Merck KGaA Darmstadt, Germany). Yeasts were detected to the genus level on blood agar.

\section{Statitistical methods}

Data were analyzed using the Excel (Microsoft) and SPSS software (SPSS). In order to determine the differences in the proportions of RVGE cases for the factors of gender, age, hospitalization and seasonal of distribution of RV, the two-tailed $\mathrm{P}$ value $\chi^{2}$ test was used. The result was significant at $p<0.05$.
Limited data exist on the importance of rotavirus in the etiology of diarrheal disease in all parts of Serbia due to a lack of detection and reporting policy of microbiological laboratories. 


\section{RESULTS}

A total of 1,156 children below eight years of age with acute GE were included in the study, with a mean age of 2.2 years. There were 144 hospitalized and 1,012 out-patients (Table 1). Pathogens were detected in 139 (11.42\%) stool samples taken from 1,156 subjects. For all tested pathogens, 1,024 (88.58\%) samples were negative. RVGE and bacterial gastroenteritis were detected in 69 and 70 cases, respectively. There was not a significant difference between the frequency of RV and bacterial infection ( $p=0.794)$.

Table 1. Detection of rotaviruses in stools samples of infants and younger children regarding gender and hospitalization

\begin{tabular}{|l|c|c|c|c|c|c|}
\hline \multirow{2}{*}{ Investigated groups } & \multirow{2}{*}{$\begin{array}{c}\text { Number of } \\
\text { subjects (\%) }\end{array}$} & \multicolumn{2}{|c|}{ Sex (\%) } & Number of & \multicolumn{2}{c|}{ Sex (\%) } \\
\cline { 3 - 4 } \cline { 6 - 7 } & Male & Female & positive (\%) & Male & Female \\
\hline Hospitalized patients & $144(12.46)$ & $87(60.42)$ & $57(39.58)$ & $28(19.44)$ & $17(60.71)$ & $11(39.29)$ \\
\hline Outpatients & $1012(87.54)$ & $577(57.02)$ & $435(42.98)$ & $41(4.05)$ & $24(58.54)$ & $17(41.46)$ \\
\hline Overall & $1156(100)$ & 664 & 492 & 69 & $41(59.42 \%)$ & $28(40.58 \%)$ \\
\hline
\end{tabular}

In hospitalized children with severe disease symptoms, rotaviral infection was diagnosed in $19.44 \%$ patients.
The overall incidence of rotavirus as the most frequent pathogen in the examined 1,156 children presented with RVGE (newborns up to 7 years of age) was $5.96 \%(69 / 1,156)$. Bacterial enteric pathogens of acute gastroenteritis were Salmonella spp., Campylobacter spp., Yersinia enterocolitica 03, Shigella flexneri, Bacillus cereus, with detection rate of $6.23 \%$ (72/1156). In one patient, Candida spp. was detected.

In hospitalized children with severe disease symptoms, rotaviral infection was diagnosed in $19.44 \%(28 / 144)$ patients. Out of $87.54 \%$ (1012/1156) ambulatory treated pediatric patients, 4.05\% (41/1012) had rotavirus in their stool samples (Table 2). A significant difference was found in the frequency of rotavirus detection between hospitalized children and those who were in community $\left(\chi^{2}=53.2197 ; p<0.001\right)$.

The overall highest incidence of RV infection (35.00\%) was among the hospitalized infants of one year of age (Table 2). The incidence of rotavirus infection in outpatients was in the range of $1.43 \%$ to $10 \%$ (Table 2).

Age distribution of acute gastroenteritis cases is presented in Table 4. The cumulative age distribution for RV-positive cases was $75.4 \%$ ( $n=$ 52) for patients younger than 24 months $(P<0.05)$ and $95.7 \%$ ( $n=$ $66)$ in those younger than five years. When the dataset was analyzed according to the age groups, for the first 24 months ( $n=52,59.8 \%$ ), rotavirus was the main pathogen $(p<0.05)$, whereas for ages $25-60$ months ( $\mathrm{n}=20 ; 47.6 \%$ ), it was Salmonella spp. $(p<0.05)$ (Table 5$)$. Furthermore, Campylobacter spp. was the main pathogen for children older than five years, but this difference was not significant $(p=0.629$ ).

In the $0-24$ months age group ( $n=87 ; 63.04 \%$ ), the cases of $R V$ ( $n=$ $52 ; 59.77 \%$ ) outnumbered the bacterial agents ( $n=23 ; 26.44 \%$ ). In the two-five years age group ( $n=42 ; 30.43 \%$ ), the main bacterial agent was Salmonella spp. (68.96\%). In nine patients older than five 
Table 2. The presence of *RVGE in different age groups

\begin{tabular}{|c|c|c|c|c|c|c|}
\hline \multirow{2}{*}{ Age } & \multicolumn{2}{|c|}{ Hospitalized patients } & \multicolumn{2}{|c|}{ Outpatients } & \multicolumn{2}{|c|}{ Total patients } \\
\hline & No & $\%$ & No & $\%$ & No & $\%$ \\
\hline $0-6$ months & $3 / 31$ & 9.68 & $3 / 87$ & 3.45 & $6 / 118$ & 5.08 \\
\hline 6 months -1 year & $9 / 41$ & 21.95 & $11 / 205$ & 5.37 & $20 / 246$ & 8.13 \\
\hline 1 year & $7 / 20$ & 35.00 & $7 / 183$ & 3.83 & $14 / 203$ & 6.90 \\
\hline 2 years & $4 / 19$ & 21.05 & $8 / 154$ & 5.19 & $12 / 173$ & 6.94 \\
\hline 3 years & $1 / 9$ & 11.11 & $4 / 117$ & 3.42 & $5 / 126$ & 3.97 \\
\hline 4 years & $3 / 12$ & 25.00 & $3 / 92$ & 3.26 & $6 / 104$ & 5.76 \\
\hline 5 years & $0 / 6$ & 0 & $3 / 94$ & 3.19 & $3 / 100$ & 3.00 \\
\hline 6 years & $0 / 3$ & 0 & $1 / 70$ & 1.43 & $1 / 73$ & 1.37 \\
\hline 7 years & $1 / 3$ & 33.33 & $1 / 10$ & 10 & $2 / 13$ & 15.38 \\
\hline Total & $28 / 144$ & 19.44 & $41 / 1012$ & 4.35 & $69 / 1156$ & 5.96 \\
\hline
\end{tabular}

*RVGE - Rotaviral gastroenteritis

Table 3. Detection of patients positive only to *RVGE in total number of patients

\begin{tabular}{|c|c|c|c|c|c|c|}
\hline \multirow{2}{*}{ Age } & \multicolumn{2}{|c|}{$\begin{array}{l}\text { Positive hospitalized } \\
\text { patients }\end{array}$} & \multicolumn{2}{|c|}{ Positive outpatients } & \multicolumn{2}{|c|}{$\begin{array}{c}\text { Total number of positive } \\
\text { patients }\end{array}$} \\
\hline & No & $\%$ & No & $\%$ & No & $\%$ \\
\hline $0-6$ months & 3 & 10.71 & 3 & 7.32 & 6 & 8.69 \\
\hline 6 months - 1 year & 9 & 32.15 & 11 & 26.82 & 20 & 28.98 \\
\hline 1 year & 7 & 25.00 & 7 & 17.07 & 14 & 20.29 \\
\hline 2 years & 4 & 14.29 & 8 & 19.51 & 12 & 17.39 \\
\hline 3 years & 1 & 3.57 & 4 & 9.76 & 5 & 7.25 \\
\hline 4 years & 3 & 10.71 & 3 & 7.32 & 6 & 8.70 \\
\hline 5 years & 0 & 0.00 & 3 & 7.32 & 3 & 4.35 \\
\hline 6 years & 0 & 0.00 & 1 & 2.44 & 1 & 1.45 \\
\hline 7 years & 1 & 3.57 & 1 & 2.44 & 2 & 2.90 \\
\hline Total & 28 & 100 & 41 & 100 & 69 & 100 \\
\hline
\end{tabular}

*RVGE - Rotaviral gastroenteritis

Table 4. Total pathogens distribution according to the patients' age

\begin{tabular}{|c|c|c|c|c|c|c|c|c|}
\hline \multirow{2}{*}{$\begin{array}{c}\text { Age groups, } \\
\ddagger \text { mo }\end{array}$} & \multirow[b]{2}{*}{ No. } & \multicolumn{7}{|c|}{ The number of identified pathogens, $\mathbf{N}^{\circ}(\%)$} \\
\hline & & $\dagger R V$ & Salmonella & $\begin{array}{c}\text { Campylo- } \\
\text { bacter }\end{array}$ & $\begin{array}{l}\text { Y. entero- } \\
\text { colitica } 03\end{array}$ & $\begin{array}{l}\text { S. flexneri } \\
2\end{array}$ & B. cereus & Coinfections \\
\hline $0-24$ & 87 & $52 *(75.4)$ & $14(38.9)$ & $18(62.1)$ & $4(80.0)$ & 0 & $1(100)$ & $2(66.7)$ \\
\hline $25-60$ & 42 & $14(20.3)$ & $20 *(55.6)$ & $7(24.1)$ & $1(20.0)$ & $1(100)$ & 0 & $1(33.3)$ \\
\hline$>60$ & 9 & $3(4.3)$ & $2(5.5)$ & $4(13.8)$ & 0 & 0 & 0 & 0 \\
\hline Total & 141 & $69(100)$ & $36(100)$ & $29(100)$ & $5(100)$ & $1(100)$ & $1(100)$ & $3(100)$ \\
\hline
\end{tabular}

${ }^{*} p<0.05, \chi^{2} ; \dagger \mathrm{RV}-$ Rotavirus; $\ddagger$ microorganism 
Table 5. Distribution of age groups according to isolated pathogens

\begin{tabular}{|c|c|c|c|}
\hline \multirow{2}{*}{ Pathogens } & \multicolumn{3}{|c|}{ Age Groups, Nº (\%) } \\
\hline & $0-24$ Months & $25-60$ Months & $>60$ Months \\
\hline Rotavirus ( $\mathrm{n}=69$ ) & $52 *(59.8)$ & $14(33.3)$ & $3(33.3)$ \\
\hline Salmonella spp. $(\mathrm{n}=36)$ & $14(16.1)$ & $20 *(47.6)$ & $2(22.2)$ \\
\hline Campylobacter spp. $(n=29)$ & $18(20.7)$ & $7(16.7)$ & $4(44.5)$ \\
\hline Y. enterocolitica $03(n=5)$ & $4(4.6)$ & $1(2.4)$ & 0 \\
\hline S. flexneri $2(n=1)$ & 0 & $1(2.4)$ & 0 \\
\hline Bacillus cereus $(n=1)$ & $1(1.1)$ & 0 & 0 \\
\hline Coinfections $(n=3)$ & $2(2.3)$ & $1(2.4)$ & 0 \\
\hline Total & 87 & 42 & 9 \\
\hline
\end{tabular}

${ }^{*} \mathrm{P}<0.05, \chi^{2}$

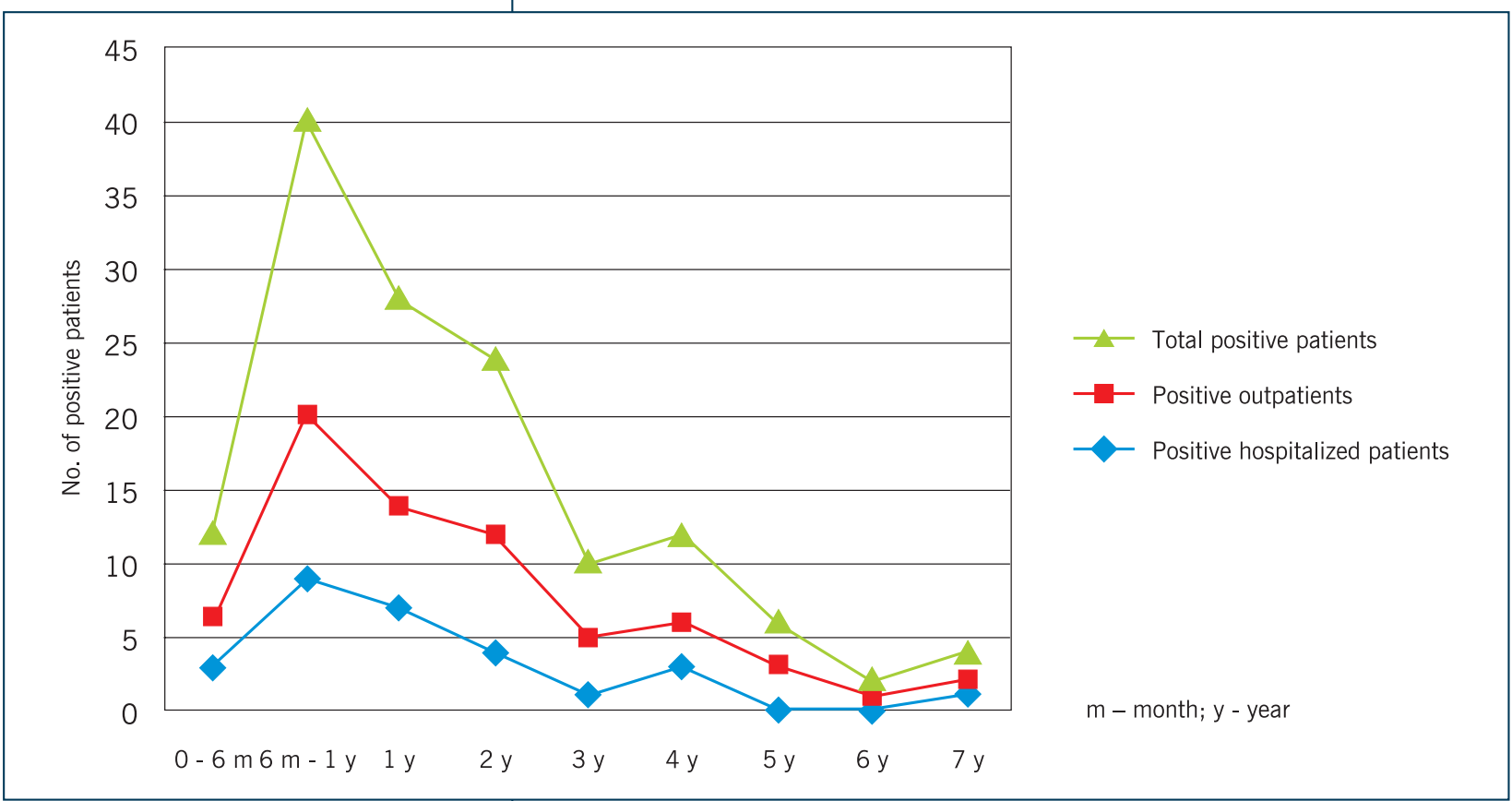

Figure 1.

The presence of positive RVGE patient in different age groups

years of age, and in six (66.67\%) cases, bacterial pathogens were detected, with Campylobacter spp. ( $n=4 ; 44.5 \%$ ) being the most common. In this group, RV was identified in three patients.

The highest incidence of total rotavirus infection was among the patients less than one year of age $-37.68 \%$ (26/69). Rotavirus infection was also diagnosed in $42.86 \%(12 / 28)$ hospitalized infants ( $0-1$ year) with gastroenteritis (Figure 1). In all investigated children up to five years of age, the incidence of rotavirus infection was $95.65 \%(66 / 69)$.

RVGE was detected more frequent in males (41/69) than in females (28/69), as well as in hospitalized patients $17 / 28$ (60.71\%) compared to outpatients $11 / 28(39.29 \%)(P=0.1176)$. By the conventional criteria, this difference was not statistically significant. Of 1,156 children tested, non-viral pathogens were found in 6.23\% (1156/72). 
The most frequently isolated pathogens were Campylobacter spp. and Salmonella Enteritidis (group D). RV alone was detected in $46.48 \%$ (66/142) of positive findings, while non-viral pathogens alone were found in $49.30 \%$ (70/142). Non-viral GE etiology was represented in the following manner: $49.32 \%(36 / 73)$ by Salmonella spp., $39 \%$ (29/73) by Campylobacter spp., 6.85\% (5/73) by Yersinia enterocolitica $03(5 / 73)$ and $1.37 \%(1 / 73)$ by Shigella spp., Bacillus cereus and Candida sp. each (Table 7).

Mixed bacterial/viral infection was detected in $0.26 \%$ (3/1156) of investigated children (Table 6). In 139 GE patients with confirmed enteropathogens, mixed bacterial/viral infection was detected in $2.16 \%$ (3/139).

One of 69 positive hospitalized pediatric patients with RVGE had at the same time the infection caused by Salmonella group B (S. Typhimurium), and two outpatients were co-infected with Campylobacter spp.
RVGE was detected more frequent in males than in females.

Table 6. Etiologyof gastroenteritis in investigated patients 7 years of age and younger

\begin{tabular}{|l|c|c|}
\hline \multicolumn{1}{|c|}{ Pathogen } & \multicolumn{2}{c|}{ No. (\%) of children } \\
\hline$\dagger R V$ alone & 66 & $(5.71)$ \\
\hline Mixed infection (RV and bacterial pathogen) & 3 & $(0.26)$ \\
\hline RV +Salmonella species & 1 & $(0.087)$ \\
\hline RV +Shigella species & 0 & $(0.00)$ \\
\hline RV + Campylobacter species & 2 & $(0.173)$ \\
\hline Non-viral enteropathogens alone & 70 & $(6.05)$ \\
\hline Not detected & 1017 & (87.98) \\
\hline
\end{tabular}

†RV - Rotavirus

Table 7. The frequency of isolated non-viral pathogens in children with * GE

\begin{tabular}{|l|c|}
\hline Microorganism & No (\%) \\
\hline Salmonella & $36(49.32)$ \\
\hline Salmonella group D & $29(39.73)$ \\
\hline S. Enteritidis & $5(6.85)$ \\
\hline Salmonella group B & $1(1.37)$ \\
S. Typhimurium & $1(1.37)$ \\
S. Abony & $29(39.73)$ \\
\hline Salmonella group C1 & $5(6.85)$ \\
\hline Campylobacter spp. & $1(1.37)$ \\
\hline Yersinia enterocolitica O3 & $1(1.37)$ \\
\hline Shigella flexneri 2a & $1(1.37)$ \\
\hline Bacillus cereus & $73(100)$ \\
\hline Candida spp. & \\
\hline Total non-viral pathogens & \\
\hline
\end{tabular}

${ }^{*} \mathrm{GE}$ - gastroenteritis 
Table 8. Monthly distribution of bacterial and viral pathogens

\begin{tabular}{|l|c|c|c|c|c|c|}
\hline \multirow{3}{*}{ Months } & \multicolumn{7}{|c|}{ The number of isolated pathogens } \\
\cline { 2 - 7 } & Rotavirus & Salmonella & Campylobacter & Y. enterocolitica & S. flexneri & B. cereus \\
\hline January & 7 & 3 & 0 & 0 & 0 & 0 \\
\hline February & 7 & 4 & 1 & 1 & 0 & 0 \\
\hline March & 9 & 0 & 1 & 1 & 0 & 0 \\
\hline April & 11 & 2 & 5 & 0 & 0 & 0 \\
\hline May & 7 & $8^{*}$ & 4 & 1 & 0 & 1 \\
\hline June & 4 & 4 & 2 & 0 & 0 & 0 \\
\hline July & 1 & 6 & 5 & 1 & 0 & 0 \\
\hline August & 2 & 1 & 0 & 0 & 1 & 0 \\
\hline September & 4 & 4 & 4 & 0 & 0 & 0 \\
\hline October & 6 & 2 & 2 & 0 & 0 & 0 \\
\hline November & 5 & 1 & 3 & 1 & & 0 \\
\hline December & 6 & 1 & 29 & & 1 & 0 \\
\hline Total & 69 & 36 & & & & 0 \\
\hline
\end{tabular}

$* \mathrm{P}<0.05, \chi^{2}$

Figure 2.

The monthly prevalence of RVGE during the investigated period

Regarding the occurrence of

$\mathrm{RV}$ infection in relation to season, the highest prevalence of GE was recorded in the winter/spring season, with its maximum in

April.

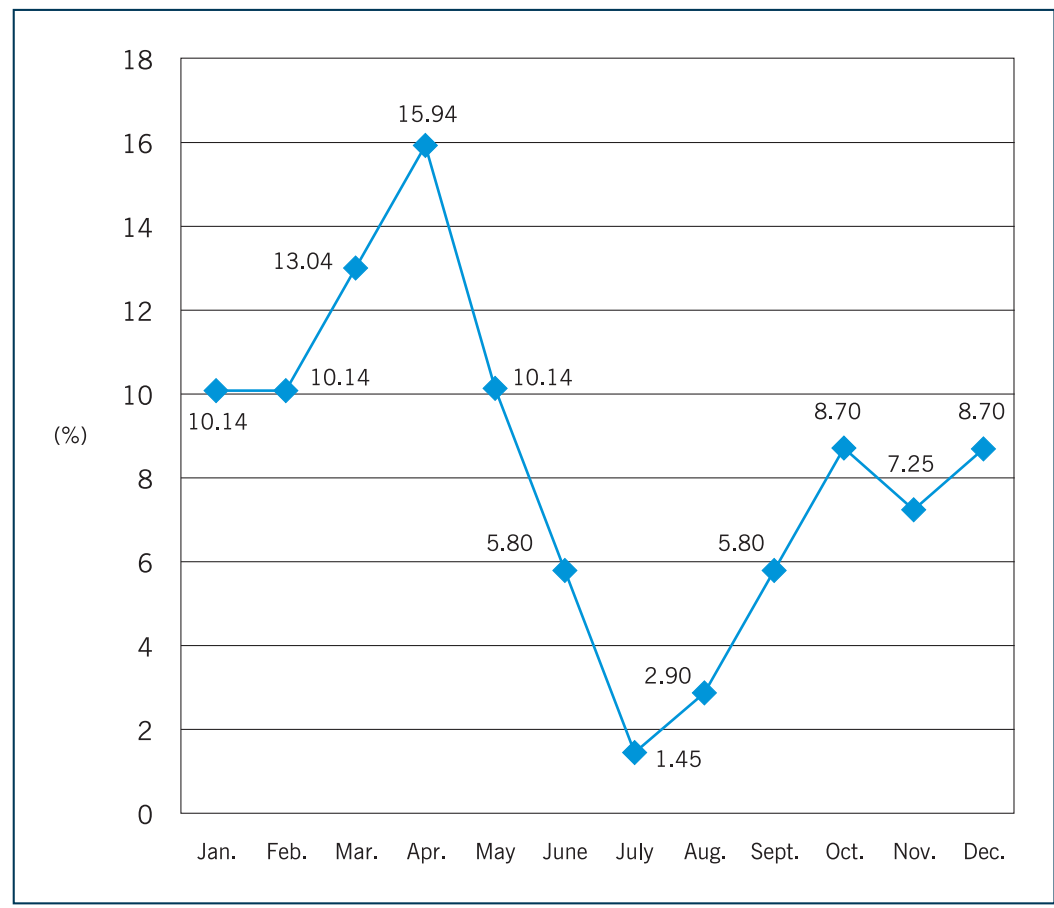

Regarding the occurrence of RV infection in relation to season, the highest prevalence of GE was recorded in the winter/spring season, with its maximum in April (the two tailed $P=0.1825$, by the conventional criteria, this difference was not statistically significant), $\mathrm{n}=11 ; 15.94 \%$ (Table 8 and Figure 2, 3). A decrease in RVGE occurred in the summer, with the lowest incidence in July (1.45\%) (Figure 2). A statistically significant difference was found in the occurrence of rotavirus infection between summer months and other seasons of the year (Chi-square test). The two-tailed $P$ value equals 


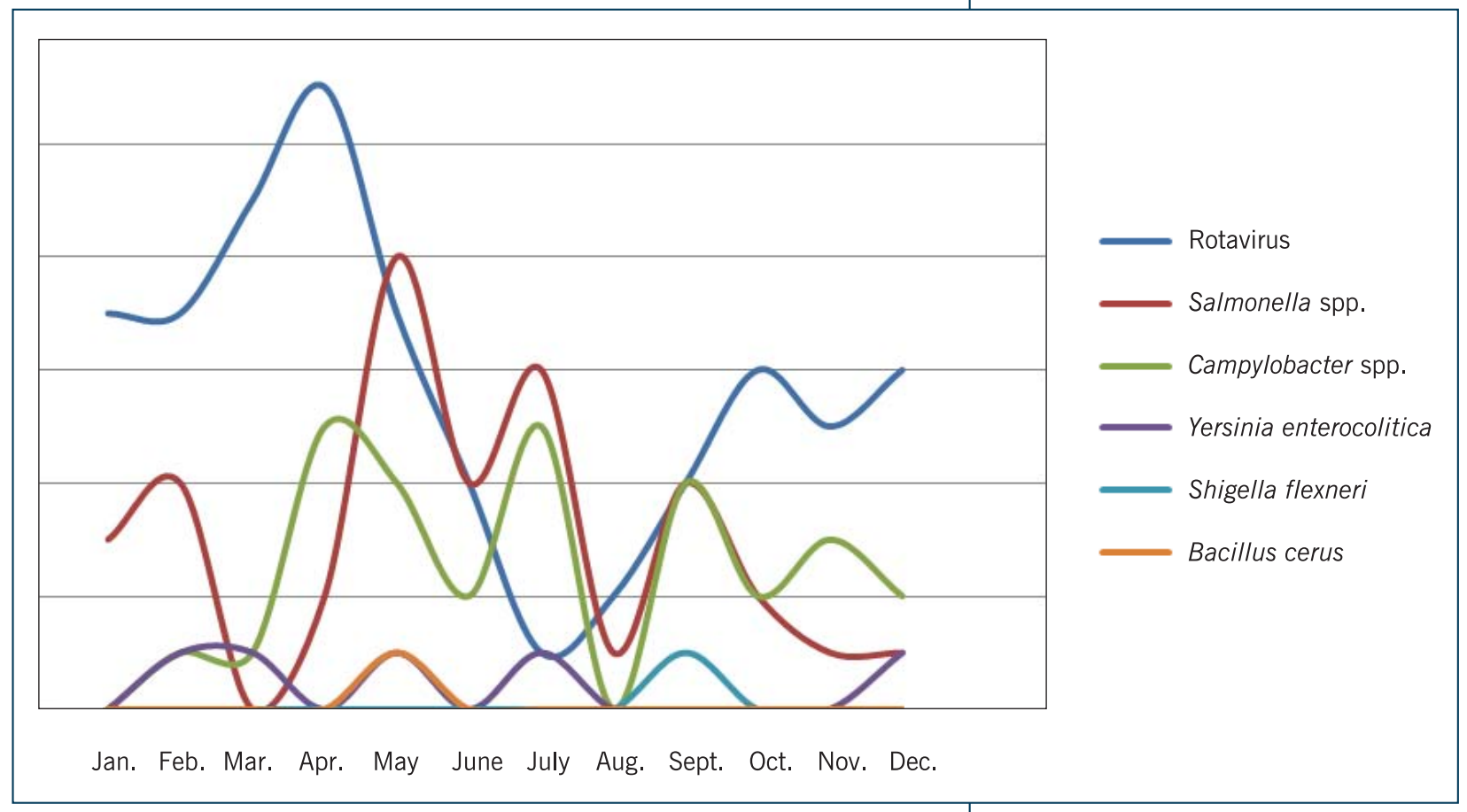

$0.0063(p<0.01)$. By the conventional criteria, this difference was considered to be highly statistically significant. The peak number of Salmonella spp. cases, which occurred in May ( $n=8 ; 22.22 \%$ ), was statistically significant (the two tailed $P=0.0453$ ), while there was not any cases in March (Figure 3).

\section{DISCUSSION}

Acute GE is one of the most common infectious diseases with variable etiology depending on the age, demographic features and seasonality in both developed and developing countries. In addition to the bacterial causes such as Salmonella spp., C. jejuni, Shigella spp., viruses (rotavirus, norovirus, adenovirus, astrovirus) have been reported as etiological agents. It is thought that viruses affect all age groups and are responsible for the majority of $G E$ cases $[16,17,18]$. Among the patients with diarrheal illness, there is a large group with indeterminate etiology, and therefore an accurate diagnosis is required for an effective treatment and prognosis.

Since we examine samples from clinic and outpatients, but not patients in emergency unit, it is possible that it could influence the positivity of the obtained results. Moreover, RV vaccine is not part of the vaccination policy in Serbia.

In this study, pathogens were detected in $11.42 \%$ stool samples from 1,156 children under eight years of age, with acute GE. However, the most frequent pathogen detected was rotavirus (12.7\%). Other viruses were not searched for. Bacterial enteric pathogens of acute gastroenteritis included Salmonella spp., Campylobacter spp., Yersinia enterocolitica 03, Shigella flexneri, Bacillus cereus, with detection rates of $6.23 \%$.

Figure 3.

Seasonal distribution of acute gastroenteritis agents

In this study, the most frequent pathogen detected was rotavirus. 
RVGE was detected more frequently in hospitalized patients than in outpatients and the most affected group included infants aged six months to one year of age.
At the pediatric emergency clinic of a university hospital in Istanbul, during 12 months of observation, rotavirus was the most frequent pathogen, with a rate of $12.7 \%$ (75/588) [19]. In Papua, New Guinea, rotavirus (25.6\%) and adenovirus (11.6\%) were the enteric pathogens most commonly detected [20]. In children attending day care who experienced substantial gastrointestinal infections due to circulating seasonal enteropathogens in the day care environment in the Netherlands in $2010-2013$, rotavirus was detected in $11 \%$, norovirus in $10 \%$ and astrovirus in $7 \%$. The authors demonstrated that circulating viruses, rather than bacteria, contribute to seasonal gastroenteritis experienced by children in day care [21].

In this study, RVGE was detected more frequently in hospitalized patients than in outpatients and the most affected group included infants aged six months to one year of age. RVGE was reported in $32.15 \%$ of hospitalized children, in $26.82 \%$ of outpatient children, and overall in $28.98 \%$ (Table 3 ). It appeared that this group of patients comprised the mayor group seeking medical attention. The highest rate of RV infection has been reported in patients 6 to 24 months of age [8] in both developed and non-industrialized countries. Concerning the RV positive cases, $28.0 \%$ were younger than 24 months, $57.3 \%$ were between $25-60$ months, and $85.3 \%$ were younger than five years in Pediatric Emergency Unit of Yeditepe University Hospital, Istanbul, Turkey [19]. In Papua, New Guinea, an analysis of the age distribution of infections between the children aged $<1$ year and children aged 1-5 years showed no significant difference in the detection rate of pathogens between the two age groups.Young children were much more likely to be admitted to hospital with acute gastroenteritis than older children [20]. In Palermo, Sicilia (Italy), the mean and median ages were 46.3 and 25.8 months, respectively (range, 4-163.6 months) [22].

The overall gender distribution of $69 \mathrm{RV}$ positive children revealed the proportion of $59.42 \%$ (41/69) for male and $40.58 \%$ (28/69) for female patients. RVGE was detected more frequently in males than in females, as in $17 / 28(60.71 \%)$ hospitalized and in $41 / 69$ (59.42\%) outpatients, without statistical significance. We could conclude that gender does not seem to influence the susceptibility to RV similarly to the previous studies [20, 22, 23].

In this study of 1,156 hospitalized patients and outpatients, the most frequently isolated bacterial pathogens were Salmonella spp.: $S$. Enteritidis (29), S. Typhimurium (5), S. Abony (1), S. Infantis (1) Campylobacter spp. (29) and Yersinia enterocolitica 03 (5). The ratio viral vs bacterial infections was almost the same 69:72. The review of clinical records of patients with an acute GE, aged less than 15 years presenting to the pediatric emergency department of a Portuguese district hospital over a 30-month period, revealed that of 216 stool samples, 98 (45\%) were positive: Campylobacter spp. was identified in $50 \%$, Salmonella spp. in $28 \%$, Yersinia enterocolitica in $10 \%$, Aeromonas spp. in 9\% and Escherichia coli 0157 in 3\% [24]. At the University hospital in Istanbul, Turkey, bacterial enteric pathogens of 
acute GE were Salmonella spp. and $C$. jejuni, with the detection rates of $25.6 \%(21 / 82)$ and $18.3 \%(15 / 82)$, respectively [19]. In a one-year investigation of hospitalized patients in Palermo, Sicily, Italy, the bacterial pathogen was detected in 127 (59.1\%) cases. Monobacterial infections were detected in 26 (12.1\%) patients (Salmonella spp. in 18, Shigella spp. in 3, C. jejuni in 5 pts), while single viral infections were found in 80 (37.2\%) patients [22]. In Papua, New Guinea, Shigella spp. were the bacterial pathogens most commonly detected (26.6\%) [20]. EPEC strains were detected in $8.5 \%$ of patients. ETEC strains were detected in $11.1 \%$ of the samples. Campylobacter spp. was detected in $4.0 \%$, while Salmonella spp. occurred sporadically. $V$. cholerae was not detected in any patient. Our results were more similar to the results obtained in Mediterranean Basin (part of Istanbul, Palermo) than in New Guinea in Oceania (the eastern half of the island of New Guinea and islands in Melanesia) a region north of Australia. Climate, geographic, demographic and other factors might influence the differences in gut microbiota.

The indistinguishable clinical presentation of gastroenteritis in children, together with the diversity of enteropathogens, makes the assessment of individual contributions of enteropathogenic agents that may cause gastroenteritis more challenging.

Mixed infections were detected at a high frequency $(22.1 \%)$ in Papua, New Guinea, (20.7\%) in Tanzania, as well as in other developing settings such as Jordan (15.5\%), Libya (13.8\%), Vietnam (13.5\%), and Brazil (11.0\%). On the contrary, co-infections are typically reported at lower frequency in the developed milieu such as Italy (9.8\%), Denmark $(1.9 \%)$, and France $(1.1 \%)$, as in our country $(2.16 \%)$. These findings might reflect low levels of sanitation and hygiene in the developing countries [20].

We have found $0.26 \%$ of RV mixed infections of total investigated children and in $2.21 \%$ of those with positive findings. This result was similar to those reported in UK (2\%) [25] and other developed countries. The detected co-infections were RV and Salmonella spp. in one patient and RV with Campylobacter spp. in two patients. In Papua, New Guinea, the combination of the pathogens Shigella $(13.1 \%)$ and rotavirus (11.1\%) was most commonly detected in mixed infections [20]. At the pediatric emergency of a University hospital in Istanbul during 2009, in 184 positive stool samples only two cases of coinfection with bacteria-virus were recorded: in one case rotavirus, adenovirus and Salmonella spp., and in the other case adenovirus and Salmonella spp. [19]. In the study in Sicily in hospitalized patients, viral bacterial coinfection was present in $4.6 \%$ cases, viral/viral coinfection in further $4.6 \%$, and double-viral and bacterial coinfection in $0.5 \%$ cases [22]. Mixed bacterial viral infection presents more severe clinical manifestation, changing the gut microbiota as well [26].

RVGE is considered to be a relevant cause of peditric nosocomial diarrhhea as well. The overall incidence of RVGE in hospitalized children
The indistinguishable clinical presentation of gastroenteritis in children, together with the diversity of enteropathogens, makes the assessment of individual contributions of enteropathogenic agents that may cause gastroenteritis more challenging. 
Rotaviruses are the substantial factor in the etiology of acute diarrheal diseases in the town of Nis, Serbia, and the surrounding area, especially among hospitalized patients in winter and early spring season. in Europe is from $31 \%$ to $87 \%$ of nosocomial diarrhea [27]. One investigation in Poland (2006-2010) revealed that the mean proportion of nosocomial RVGE among all rotavirus infections was $24 \%$, with the highest rates in children younger than two years [27, 28]. In the investigated period, we did not find any nosocomial infections caused by $\mathrm{RV}$ in hospitalized children.

In a Polish study, $69 \%$ of rotavirus infections occurred in the autumn and winter season [29], which is similar to other data obtained for the temperate or subtropical regions in developed countries [25, 27]. However, our data indicated the highest rate of RGVE in winter/spring season, with its maximum in April. In Turkey, RV infection was most frequent in the period January - April [19]. Rotavirus cases may vary by geographical location: in temperate climates most cases are observed in fall, winter and spring months [11], while in tropical countries there are not seasonal peaks [12]. However, in Burkina Faso among the children under five years of age, rotavirus infections occur more often in the dry season when compared to the wet season $(p=0.03)$ [30].

Although viral etiology of GE can be recognized using numerous simple and fast tests based on ELISA and immunchromatography, due to which unnecessary antibiotic use is thus avoided, molecular PCR-based techniques can be used to improve the overall diagnostic efficacy of viral and bacterial GE and to detect types and subtypes, which should promote various types of studies.

\section{CONCLUSION}

Although our study was not a case-control study, our investigation provided some important data on the presence of enteric pathogens in children presenting with GE. Our data of RVGE in children, during this 18-month research period, indicate that rotaviruses are the substantial factor in the etiology of acute diarrheal diseases in the town of Nis, Serbia, and the surrounding area, especially among hospitalized patients in winter and early spring season. In addition to RVGE, Salmonella spp. and Campylobacter spp. were the major contributors to childhood diarrheal illnesses in our setting.

\section{REFERENCES}

[1] World Health Organization. The treatment of diarrhea, a manual for physicians and other senior health workers. Geneva, Switzerland: 2005. Available at URL: http://whqlibdoc.who.int/publications/2005/ 9241593180.pdf.

[2] World Health Organization Regional Office for Europe. European Health for all database. World Health Organization. Accessed 2006. Available at URL: http://www.euro.who.int/hfadb

[3] Dormitzer F, Desselberger U. Fields.Virology: Chapter 5. In Oxford Textbook of Medicine: Infection $5^{\text {th }}$ edition. Warrell D, Cox TM, Firth J, Török E, eds. Philadelphia: Lippincott Williams \& Wilkins; 2012. p. 1361.

[4] Gentsch JR, Voods PA, Ramachandran M, et al. Review of G and P typing results from a global collection of rotavirus strains: implications for vaccine development. J Infect Dis. 1996; 174 Suppl 1: S30-S36. 
[5] Uhnoo I, Olding-Stenkvist E, Kreuger A. Clinical features of acute gastroenteritis associated with rotavirus, enteric adenoviruses, and bacteria. Arch Dis Child. 1986; 61(8): 732-8.

[6] Jalilvand S, Marashi SM, Tafakhori A, et al.Extraintestinal Involvement of Rotavirus Infectionin Children.Arch Iran Med. 2015;18(9):604-5. doi: 0151809/AIM.0010.

[7] Hagbom M, Sharma S, Lundgren O, et al. Towards a human rotavirus disease model. Curr Opin Virol 2012; 2: 408-18.

[8] Williams CJ, Gray K, Pebody RG, et al. Survey of Rotavirus Surveillance, Laboratory capacity and disease burden in Eastern part of the WHO European Region. 2008. Eurosurveillance. 13(34); 1-7. Available at URL: http://www.eurosurveillance.org/ViewArticle.aspx?Articleld=18959

[9] Parashar UD, Burton A, Lanata C, et al. Global mortality associated with rotavirus disease among children in 2004. J Infect Dis 2009; 200: S915.

[10] Tate JE, Burton AH, Boschi-Pinto C, et al. WHO-coordinated Global Rotavirus Surveillance Network. 2008 estimate of worldwide rotavirusassociated mortality in children younger than 5 years before the introduction of universal rotavirus vaccination programmes: a systematic review and meta analysis. Lancet Infect Dis. 2012; 12: 136-41.

[11] Ryan MJ, Ramsay M, Brown D, et al. Hospital admissions attributable to rotavirus infection in England and Wales. J Infect Dis. 1996; 174 Suppl 1: S12-S18.

[12] Cunliffe NA, Kilgore PE, Bresee JS, et al. Epidemiology of rotavirus diarrhoea in Africa: a review to assess the need for rotavirus immunization. B World Health Organ. 1998; 76: 525-537.

[13] Altindis M, Yavru S, Simsek A, et al. Rotavirus infection in children with acute diarrhea as detected by latex agglutination, ELISA and polyacrylamide gel electrophoresis. Indian Pediatr. 2004; 41(6):590-4.

[14] Amar CF, East CL, Gray J, Iturriza-Gomara M, et al. Detection by PCR of eight groups of enteric pathogens in 4,627 faecal samples: reexamination of the English case-control Infectious Intestinal Disease Study (1993-1996). Eur J Clin Microbiol Infect Dis. 2007; 26(5): 31123.

[15] Fischer TK, Gentsch JR. Rotavirus typing methods and algorithms. 2004. Rev. Med. Virol 14(2): 7182.

[16] Bhutta ZA. Acute gastroenteritis in children. In: Kliegman R, editor. Nelson Textbook of Pediatrics, $19^{\text {th }}$ edition. Philadelphia: Elsevier/ Saunders; 2011, p. 1323-39.

[17] Gul M, Garipardic M, Ciragil P, et al. [Rotavirus gastroenteritis in children between the ages of 0-5, and adenovirus type 40/41 Investigation]. AnkemDerg.2005; 19(2): 64-7. [Article in Turkish]

[18] Hart CA, Cunliffe NA. Diagnosis and causes of viral gastroenteritis. CurrOpin Infect Dis.1996; 9(5): 333-9.

[19] Bicer S, Col D, Erdag GC, Girai T, et al. A Retrospective Analysis of Acute [4] Gastroenteritis Agents in Children Admitted to a University Hospital Pediatric Emergency Unit. Jundishapur J Microbiol 2014; 7(4): e9148.

[20] Soli KV, Maure T, Kas MP, et al. Detection of enteric viral and bacterial pathogens associated with paediatric diarrhoea in Goroka, Papua New Guinea. Int J Infect Dis. 2014; 27: 54-8.

[21] Enserink R, van den Vijngaard C, Bruijning-Verhagen $P$, et al. Gastroenteritis Attributable to 16 Enteropathogens in Children Attending Day Care. Significant Effects of Rotavirus, Norovirus, Astrovirus, Cryptosporidium and Giardia. Pediatr Infect Dis. J2015; 34(1): 5-10.

[22] Colomba C, De Grazia S, Giammanco GM, et al. Viral gastroenteritis in children hospitalised in Sicily, Italy. Eur J ClinMicrobiol Infect Dis.2006; 25(9): 570-5. 
[23] Ford L, McEwen S,Glass K.Trends of viral gastroenteritis in the Australian Capital Territory.Commun Dis Intell (2018).2018;42. pii: S22096051(18)00010-6.

[24] Soares AT, Couto C, Romao P, et al. [Acute gastroenteritis by cambylobacter spp: a retrospective study of a paediatric emergency department]. Acta Med Port. 2014; 27(5): 556-60. [Article in Portuguese]

[25] Iturriza-Gómara M, Green J, Brown DW, et al.Molecular epidemiology of human group A rotavirus infections in the United Kingdom between 1995 and 1998. J Clin Microbiol. 2000; 38(12): 4394-401.

[26] Mathew S, Smatti MK, Al Ansari K, et al.Mixed Viral-Bacterial Infections and Their Effects on Gut Microbiota and Clinical Illnesses in Children. Sci Rep. 2019; 29; 9(1):865. doi: 10.1038/s41598-018-37162-w

[27] Gleizes O, Desselberger U, Tatochenko V, et al.Nosocomial rotavirus infection in European countries: a review of the epidemiology, severity and economic burden of hospital-acquired rotavirus disease.Pediatr Infect Dis J.2006; 25 Suppl 1:S12-21.

[28] Muhsen K, Shulman L, Rubinstein U, et al.Incidence, characteristics, and economic burden of rotavirus gastroenteritis associated with hospitalization of Israeli children $<5$ years of age, 2007-2008. J Infect Dis.2009; 200: Suppl1:S254-63.

[29] Nitsch-Osuch A, Kuchar E, Kosmala A, et al.Nosocomial rotavirus gastroentero colitis in a large tertiary paediatric hospital in Warsaw, 2006-2010. Arch Med Sci. 2013; 9(3): 493-8.

[30] Ouedraogo N, Ngangas SM, Bonkoungou IJ, et al.Temporal distribution of gastroenteritis viruses in Ouagadougou, Burkina Faso: seasonality of rotavirus.BMC Public Health. 2017;17(1):274. doi: 10.1186/s12889017-4161-7. 